\title{
Mencandera Industri Perbankan Syariah Indonesia: Tinjauan Kritis Pasca UU 21 Tahun 2008
}

Oleh: Aam Slamet Rusydiana*

\begin{abstract}
After the Act No. 21 year 2008 has been legalized, shariah banking industries will grow rapidly. The content of rules ise possible to push the growth of shariah banking in Indonesia. But in the fact, there are some important thing related to instrument and shariah banking product showsn less ideal in this banking industries. The article below tries to find and predict deeper about condition of shariah banking in Indonesia after the Act No. 21 year 2008 has been formalized. The result revealed that after the rules had been existed, in short term we can not see the positive effect, significantly. In other case, we find a lot of thing that not come from genuine shariah banking, that in the future will have negative impact in the long term, such as: SBI Shariah instrument, shariah credit card, the domination of non PLS and other thing else.
\end{abstract}

Keywords: Perbankan Syariah, UU 21 Tahun 2008, tinjauan kritis, dan industri.

\section{Pendahuluan}

Industri perbankan syariah kini memasuki era baru. UU Perbankan Syariah (UU PS) yang memuat 70 pasal, resmi disahkan oleh Dewan Perwakilan Rakyat pada 17 Juni 2008 dan ditandatangani oleh pemerintah sekitar pertengahan Juli. Dukungan regulasi ini dicandera (baca: diprediksi) akan memberi dampak positif bagi perbankan syariah nasional. Perkembangan pesat perbankan syariah selama ini tidak bisa dilepaskan dari dukungan regulasi. Kehadiran bank syariah pertama pada 1992, Bank Muamalat, terjadi berkat dukungan UU No. 7/1992.

* Staf peneliti pada Institute for Research and Community Empowerment Tazkia (IRCETAZKIA) Bogor, Indonesia. Juga sebagai asisten peneliti Direktorat Pusat Pendidikan dan Studi Kebanksentralan (PPSK) Bank Indonesia. Email: tasik_pisan@ yahoo.com. Penulis mengucapkan banyak terima kasih pada Hasna Maliha, mahasiswa STEI Tazkia jurusan Akuntansi Syariah yang telah membantu dalam penulisan paper ini, terutama dalam hal pengumpulan data dan literatur. Email: tasik_pisan@yahoo. com 
Perkembangan perbankan syariah secara pesat sejak 1999 juga merupakan hasil dari dukungan regulasi yang memadai yaitu UU No. 10/1998 dan UU No. 23/1999 yang kemudian diperkuat oleh UU No. 3/2004.

Pertanyaannya kemudian adalah, seberapa besar dampak UU PS bagi perkembangan industri perbankan syariah ke depan? Apakah target share 5\% dapat dicapai? Hal-hal apa saja yang masih membutuhkan perhatian lebih dalam untuk pengembangan perbankan syariah? Rumusan masalah dalam tulisan ini dapat disusun dan diketahui dengan memberikan jawaban dari beberapa pertanyaan di atas.

Pada penelitian ini penulis mencoba menganalisis lebih jauh beberapa hal yang menjadi tantangan yang dihadapi oleh industri perbankan syariah Indonesia yang mengakibatkan kurang naturenya lembaga intermediasi ini, berikut tinjauan agak mendalam yang sifatnya otokritik.

\section{Hukum Ekonomi Islam di Indonesia}

Indonesia merupakan negara besar, baik dari segi teritorialnya (luas wilayahnya) maupun dari segi jumlah penduduknya. Dilihat dari sudut penduduknya juga memiliki keberagaman baik etnis, adat dan agamanya. Artinya, untuk merealisasikan sistem ekonomi kerakyatan bukanlah sebuah persoalan yang mudah. Banyak hal yang harus diperhatikan termasuk salah satunya adalah masalah ketersediaan lembaga keuangan yang dapat berdiri tegar dalam segala kondisi. Krisis telah mengajarkan banyak hal, salah satu diantaranya menyangkut keberadaan perbankan Syariah. Bank Syariah ternyata lebih tahan krisis dan tidak menyulitkan negara. Sementara bank konvensional menjadi parasit bagi perekonomian negara karena menguras APBN tiap tahun untuk membayar hutang dan bunga obligasi rekap. ${ }^{1}$ Kuatnya daya tahan perbankan syariah dalam mengahadapi guncangan krisis setidaknya memberi sebuah solusi untuk dijadikan sebagai konsep dalam melakukan pemberdayaan ekonomi masyarakat.

Lebih jauh dari hal tersebut, pemberlakuan Undang-Undang No. 10 Tahun 1998 tentang perubahan atas Undang-Undang No. 7 Tahun 1992 tentang Perbankan merupakan sebuah momentum pengembangan perbankan syariah di Indonesia. Undang-undang ini menjadi batu pijakan berdirinya sistem ekonomi Islam di Indonesia dalam menjawab tantangan krisis yang ada. Apalagi UU Perbankan Syariah terbaru yang telah disahkan parlemen pada Bulan Juni lalu, menjadi sebuah landasan hukum yang kuat dalam rangka pengembangan perbankan syariah Indonesia ke depan.

Berkaitan dengan persoalan transformasi hukum Islam ke dalam hukum nasional, apabila diperhatikan sejarah hukum di Indonesia menurut Ramadhani

${ }^{1}$ Syakir Sula dan Agustianto, Republika. 
akan dijumpai tiga sistem hukum yang pernah berlaku, ${ }^{2}$ yaitu: Pertama, dilihat dari segi pluralitas jenis penduduknya, dapat dikatakan bahwa masyarakat Indonesia mempunyai sistem hukum yang berlaku semenjak zaman primatif disebut dengan "hukum Adat". Sedangkan dalam pengertian yang dinamis disebut dengan hukum kebiasaan (customary law) atau hukum yang hidup dalam masyarakat (living law). Kedua, dari segi agama, sudah pasti ada nilai-nilai agama yang telah diyakini bersama, dijadikan sistem kehidupan mereka dan mengatur hubungan antara sesama mereka. Ketiga, sebagai negara yang pernah dijajah selama 350 tahun, jelaslah negara penjajah tidak mungkin untuk tidak membawa sistem hukum mereka ke Indonesia, kita sebut hukum sistem Hukum Belanda atau sistem hukum Barat. ${ }^{3}$

Konsekuensi keadaan di atas terdapatnya pluralisme dalam segenap lapangan hukum di Indonesia, terutama sekali dalam lapangan hukum keperdataan, yang akhirnya Indonesia sampai saat sekarang ini tidak dapat menunjukkan Kitab Undang-Undangnya yang bersifat nasional. Tidak seperti di Negara Perancis misalkan, dapat menunjukkan Code Civilnya, atau mungkin juga seperti Swiss yang mempunyai Zivil Gezetzbuch, RRC dan Pilipina mempunyai Code Civilnya. ${ }^{4}$ Dalam konteks ini, peranan hukum agama tentunya tidak bisa tidak harus terkait dengan hukum agama Islam. Kontribusi hukum Islam ke dalam hukum ekonomi nasional merupakan suatu keharusan yang tidak dapat dipungkiri, dan hal ini merupakan sesuatu yang wajar karena penduduk terbesar negeri ini beragama Islam.

Hukum Islam dalam negara Republik Indonesia mempunyai kedudukan yang strategis, karena tidak hanya secara umum ada dalam UUD atau peraturan perundang-undangan lainnya, akan tetapi secara jelas dan terang tercantum dalam UUD 1945, dalam Pasal 29 ayat (1) jelas disebutkan bahwa negara berdasarkan Ketuhanan Yang Maha Esa.

Seperti dikutip Daud Ali, Hazairin mengemukakan bahwa kaedah fundamental dalam Pasal 29 ayat (1) itu dapat ditafsirkan dalam enam kemungkinan. Tiga di antaranya adalah'; Pertama, Dalam negara Republik Indonesia tidak boleh ada atau tidak boleh berlaku hukum yang bertentangan dengan kaidah agama yang berlaku bagi pemeluk agama. Tafsir pertama ini telah

${ }^{2}$ Rahmat Ramadhani (2008), "Perbankan Syariah Menuju Era Tinggal Landas: Kajian dalam Perspektif Hukum Ekonomi Islam Indonesia”. Makalah, hal 4.

${ }^{3}$ A. Qodry Azizy (2002) dalam Rahmat Ramadhani (2008), "Perbankan Syariah Menuju Era Tinggal Landas: Kajian dalam Perspektif Hukum Ekonomi Islam Indonesia”. Makalah, hal 5.

4 Kansil dan Christine (2000) dalam Rahmat Ramadhani (2008). "Perbankan Syariah Menuju Era Tinggal Landas: Kajian dalam Perspektif Hukum Ekonomi Islam Indonesia”. Makalah, hal 7.

5 Mohamad Daud Ali (1998). Hukum Islam dalam Peraturan Hukum Negara Indonesia. hal 45-46. 
dipergunakan sebagai pembenar atas penolakan umat Islam terhadap Rancangan Undang-undang Perkawinan yang diajukan Menteri Kehakiman pada tahun 1973, karena dalam RUU tersebut terdapat 19 butir masalah yang bertentangan dengan hukum Islam. Kedua, Negara wajib menjalankan syariat semua agama yang berlaku di Indonesia, kalau untuk menjalankan syariat itu memerlukan bantuan kekuasan negara. Ini berarti bahwa negara wajib mengatur dan menjalankan hukum yang berasal dari ajaran agama untuk kepentingan bangsa Indonesia (yang menjadi pemeluk agama bersangkutan) kalau pelaksanaannya memerlukan bantuan penyelenggara negara. Syariat yang berasal dari agama Islam, tidak hanya memuat hukum-hukum shalat atau sembahyang, zakat, puasa dan haji saja, tetapi juga mengandung "hukum dunia" baik perdata maupun publik yang memerlukan kekuasaan negara untuk menjalankannya secara sempurna. Ketiga, syariat yang tidak memerlukan kekuasan negara untuk melaksanakannya karena dapat dijalankan sendiri oleh setiap pemeluk agama yang bersangkutan. (seperti shalat dan puasa bagi umat Islam) menjadi kewajiban pribadi pemeluk agama itu sendiri untuk menjalankannya menurut ketentuan agama masing-masing. Dalam bidang hukum ekonomi, sistem dan hukum yang berkembang selama ini di Indonesia lebih mengarah kepada sistem kapitalisme, namun sistem ini sangat rentan terhadap gonjang-ganjing perekonomian yang melanda dunia, dan bahkan hingga saat sekarang ini kondisi perekonomian bangsa Indonesia masih dalam keadaan 'morat-marit' alias belum pulih.

\section{Isi dan Implikasi UU 21}

\section{A. Pokok-Pokok Pikiran}

Menurut Wibisono, secara umum UU PS memiliki beberapa tujuan utama. ${ }^{6}$ Pertama, menjamin kepastian hukum bagi stakeholders dan sekaligus memberi keyakinan bagi masyarakat untuk menggunakan produk dan jasa perbankan syariah. Hal ini terlihat dari ketentuan-ketentuan tentang jenis usaha, ketentuan pelaksanaan syariah, kelayakan usaha, penyaluran dana, larangan bagi bank syariah dan UUS, kerahasiaan bank, serta penyelesaian sengketa. Kedua, menjamin kepatuhan syariah (syariah compliance). Hal ini terlihat dari ketentuan kegiatan usaha yang tidak boleh bertentangan dengan prinsip syariah, penegasan kewenangan fatwa syariah oleh MUI, kewajiban pembentukan Dewan Pengawas Syariah (DPS) di setiap bank syariah dan UUS, serta pembentukan Komite Pengawas Syariah di Bank Indonesia (BI). Ketiga, menjamin "stabilitas sistem". Hal ini terlihat dari diadopsinya 25 Basel Core Principles for Effective Banking Supervision seperti ketentuan tentang pendirian dan kepemilikan, pemegang saham pengendali, tata kelola, prinsip kehati-hatian, kewajiban pengelolaan

${ }^{6}$ Yusuf Wibisono (2008). "Menakar UU Perbankan Syariah” . Makalah, hal 2-3. 
resiko serta pembinaan dan pengawasan. Semangat "stabilitas sistem" ini semakin terlihat jelas dengan adanya ketentuan tentang sanksi administratif dan ketentuan pidana.

Sepertinya, regulasi yang ada sudah 'on the track'. Beberapa aspek penting lain dalam UU PS nampak sudah berada pada arah yang tepat, antara lain: [1] ketentuan bahwa bank konvensional dapat dikonversi menjadi bank syariah dan larangan bank syariah dan BPRS dikonversi menjadi bank konvensional atau BPR; [2] mengizinkan kepemilikan asing secara kemitraan dengan investor domestik; [3] mendorong spin-off UUS menjadi BUS secara smooth yaitu ketika aset UUS telah mencapai 50\% dari induknya atau 15 tahun setelah berlakunya UU PS; [4] dalam hal terjadi merger atau konsolidasi bank syariah dengan bank lain, maka bank hasil merger atau konsolidasi harus menjadi bank syariah; [5] dana zakat dan sosial yang dihimpun perbankan syariah harus disalurkan ke organisasi pengelola zakat; [6] bank syariah dapat menghimpun wakaf uang; [7] penegasan dan landasan yang kuat untuk BPR Syariah; dan [8] kewajiban tata kelola yang baik dan penyampaian laporan keuangan berdasarkan prinsip akuntansi syariah.

\section{B. Implikasi}

Dengan kecenderungan di atas, menurut Wibisono UU PS akan memiliki dampak positif terhadap aspek kepatuhan syariah, iklim investasi dan kepastian usaha, serta perlindungan konsumen dan stabilitas sektor perbankan secara keseluruhan. ${ }^{7}$ Dari sisi supply, hal ini langsung bisa dirasakan dampaknya oleh industri dengan rencana berdirinya sejumlah BUS dan UUS baru tahun ini juga, termasuk asing. Dari sisi demand, dibutuhkan waktu lebih panjang untuk melihat dampak UU PS ini seiring proses sosialisasi.

Namun beberapa agenda penting pengembangan industri perbankan syariah nampak belum mendapat perhatian memadai. Pertama, UU PS secara umum masih minim insentif untuk membesarkan size perbankan syariah. Aturan kepemilikan asing di industri perbankan syariah nasional sudah diakomodasi, namun belum memberi insentif yang memadai. Insentif untuk konversi bank konvensional menjadi BUS atau spin-off UUS menjadi BUS, juga belum mendapat perhatian. Liberalisasi perbankan syariah domestik oleh Perpres No. 77/2007 telah berada di arah yang tepat dilihat dari aspek pengembangan size perbankan syariah. Namun harus ada upaya agar proses masuknya pemain asing ini selalu melibatkan mitra domestik sebagai mitra strategis yang sejajar, dan dengan cara mendirikan bank syariah baru atau membeli bank konvensional yang telah ada dan mengkonversinya menjadi bank syariah, bukan dengan membeli bank syariah yang telah ada. BI diharapkan mampu memberi arahan kebijakan

\footnotetext{
${ }^{7}$ Yusuf Wibisono (2008). “Menakar UU Perbankan Syariah”. Makalah, hal 5.
} 
yang tepat di sini. Namun juga harus diakui bahwa sebagian besar inisiatif lain yang dibutuhkan berada di luar wilayah UU PS ini. Karena itu maka UU PS harus segera diikuti dengan sejumlah regulasi penting lain seperti netralitas pajak untuk penyamaan level of playing field, insentif fiskal dan inisiatif yang memadai dari BI. Sejumlah negara lain telah melangkah jauh terkait hal ini. Salah satu yang paling ambisius adalah Malaysia. Untuk mempercepat peningkatan size industri dan mendorong keterkaitan sektor finansial domestik dengan global, sektor perbankan syariah Malaysia diliberalisasi pada tahun 2004 dengan penerbitan izin untuk institusi keuangan Islam asing. Kepemilikan asing di institusi keuangan Islam dinaikkan hingga 49\% dari total saham. Izin baru juga diperluas untuk perusahaan yang menjalankan bisnis perbankan syariah, takaful dan retakaful dalam mata uang internasional, di mana untuk institusi ini kepemilikan asing diperbolehkan hingga 100\%, keleluasaan operasional untuk mendirikan kantor cabang atau pembantu, dan fasilitas tax holiday selama 10 tahun berdasarkan UU Pajak Pendapatan Malaysia.

Kedua, sementara UU PS memuat aturan yang ekstensif tentang kegiatan usaha dan akad syariah yang digunakan bank syariah, namun tidak diimbangi dengan ketentuan tentang institusi yang bertugas untuk product development dan sekaligus syari'ah approval. DSN-MUI seharusnya mendapat kewenangan ini dan diperkuat dengan sumber daya agar mampu melakukan riset dan pengembangan, tidak hanya pasif menerima permintaan fatwa dari industri. Industri ini masih sangat membutuhkan produk yang beragam sesuai kebutuhan masyarakat dan dunia usaha namun tetap terjaga syari'ah compliance-nya.

Ketiga, masalah ketiadaan payung hukum lembaga keuangan mikro syariah (LKMS) belum terselesaikan. Sebagai sebuah realitas sosial, eksistensi LKMS tidak bisa diabaikan. Walau telah mengatur BPRS, namun keberadaan BMT, KJKS dan LKMS lainnya tetap tidak tersentuh. Seharusnya, ada inisiatif-inisiatif untuk mendorong LKMS menjadi sehat dan kompetitif seperti insentif LKMS untuk melebur menjadi BPRS, memperkuat linkage programme, pembuatan SOP untuk pengawasan yang efektif, dll.

\section{Tinjauan Kritis}

\section{A. Bank Syariah Pasca UU 21 Tahun 2008}

Bagaimanakah fakta empiris yang terjadi pada industri perbankan syariah pasca terbitnya Undang-Undang No 21 ini? Memang ada pandangan optimis dan pesimis. Namun itu secara mutlak terjawab oleh fakta. Faktanya jika melihat indikator perkembangan aset perbankan syariah, misalnya, memang terjadi kenaikan aset month to month. Rata-rata kenaikan adalah 0,04 hingga 0,05\% per bulan. Jika diasumsikan kenaikan tersebut adalah konstan dan tidak terjadi akselerasi yang signifikan, maka hasil simulasi menunjukkan bahwa bank syariah 
butuh waktu sekitar 2000 bulan lagi untuk mencapai 100\% share perbankan syariah Indonesia $(100 / 0,05)$ atau setara dengan lebih kurang 144 tahun. Sebuah masa yang masih amat panjang dan berliku. Belum lagi jika terjadi hal-hal yang tidak diinginkan yang kemudian menghambat perkembangan perbankan syariah. Hal ini menjadi tantangan tersendiri bagi seluruh stakeholder dan kalangan perbankan syariah Indonesia di masa mendatang.

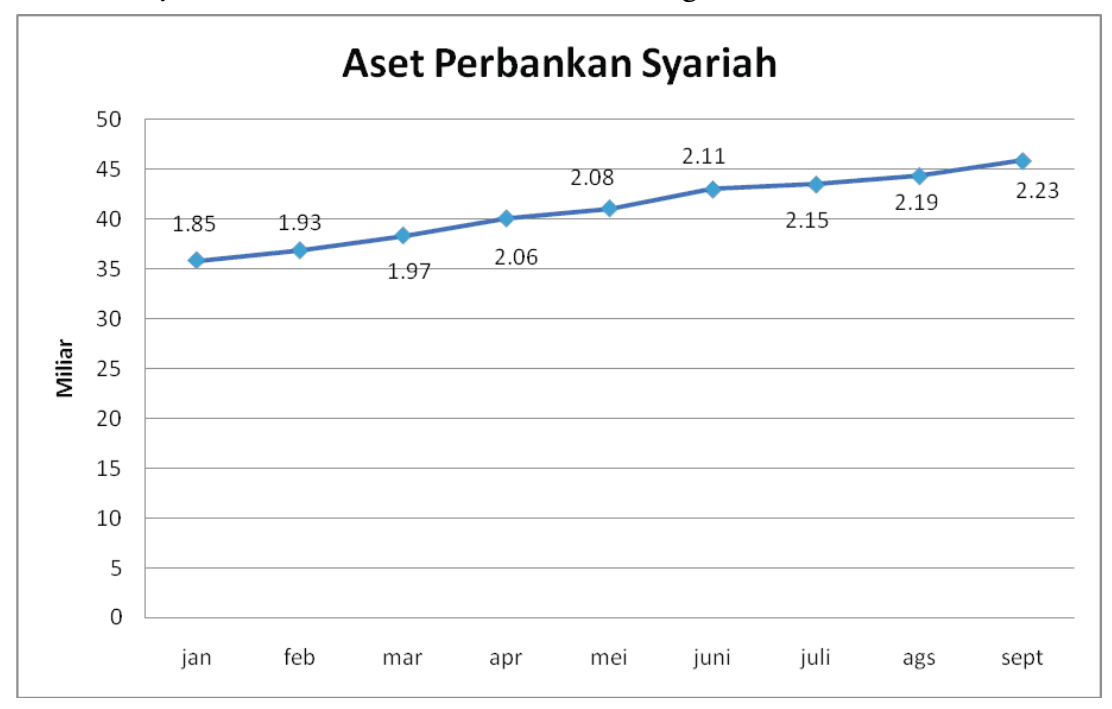

Gambar 4.1 Perkembangan Aset Perbankan Syariah Pra dan Pasca UU

\section{B. Murabahah 59 Persen}

Masalah dominasi pembiayaan nonbagi hasil harus mendapat perhatian yang serius karena masalah ini akan mendatangkan reputation risk sebagai akibat label syariah yang menempel pada lembaga keuangan ini. Masalah ini memang bukanlah masalah yang sifatnya esensial (ushul), namun sifatnya cabang (furu), karena pembiayaan bagi hasil dan nonbagi hasil sama-sama diperbolehkan secara syariah. Akan tetapi sebagian pakar berpendapat bahwa pembiayaan nonbagi hasil, khususnya murabahah, merupakan bentuk pembiayaan sekunder yang mestinya dipergunakan sementara saja pada masa awal pertumbuhan sebelum bisa menggunakan pembiayaan bagi hasil. Selain itu, pandangan mainstream berpendapat bahwa bentuk pembiayaan bagi hasillah yang menceminkan the real islamic bank. Faktanya, hingga sekitar Bulan September 2008 ini, data menunjukkan bahwa pembiayaan murabahah masih mendominasi yakni sekitar 59 persen. Bandingkan dengan pembiayaan bagi hasil (mudharabah dan musyarakah) yang hanya berangka 36 persen yang semestinya menjadi nature 
perbankan syariah Indonesia, bank bagi hasil.

Sebagaimana diketahui, masalah dominasi nonbagi hasil, khususnya murabahah, merupakan masalah yang menyertai perkembangan suatu bank syariah, karena pada tahap awal pertumbuhan (formatif) bank syariah harus menghadapi berbagai masalah lain yang menyertai pertumbuhan, khususnya membangun SDI dengan paradigma baru yang sesuai dengan tuntutan Syariah. Namun apabila dibiarkan tanpa arahan, masalah ini dapat menjadi berkepanjangan, atau dianggap sebagai bukan masalah, seperti keadaan di Malaysia.

Masalah rendahnya pembiayaan bagi hasil juga merupakan fenomena global yang tidak hanya terjadi di Indonesia, tetapi juga terjadi di negara-negara lain yang menerapkan dual banking system maupun fully Islamic banking/financial system, namun negara yang menerapkan fully Islamic banking/financial system mempunyai kemungkinan lebih besar untuk dapat mengatasi masalah ini, karena perangkat dan infrastrukturnya yang mendukung. Sudan dapat digunakan sebagai contoh negara yang berhasil meningkatkan pembiayaan bagi hasil di perbankan syariahnya.

Sebagian pakar berpendapat bahwa masalah-masalah yang ada di perbankan syariah berawal dari satu hal pokok yaitu paradigma atau mindset para pelakunya, khususnya SDI perbankan syariah. Apabila pokok masalah ini terselesaikan sebenarnya masalah-masalah lain menjadi hilang dengan sendirinya. Contoh di Sudan menunjukkan bahwa bank yang dari awal berprinsip syariah terbukti tidak mengalami banyak kesulitan dan sukses dalam menyalurkan pembiayaan bagi hasil, sedangkan bank yang harus mengkonversi diri menjadi bank syariah, karena peraturan, tidak begitu sukses di lapangan. Gambar berikut ini menampilkan data porsi pembiayaan bank syariah di Indonesia sejak tahun 2002.

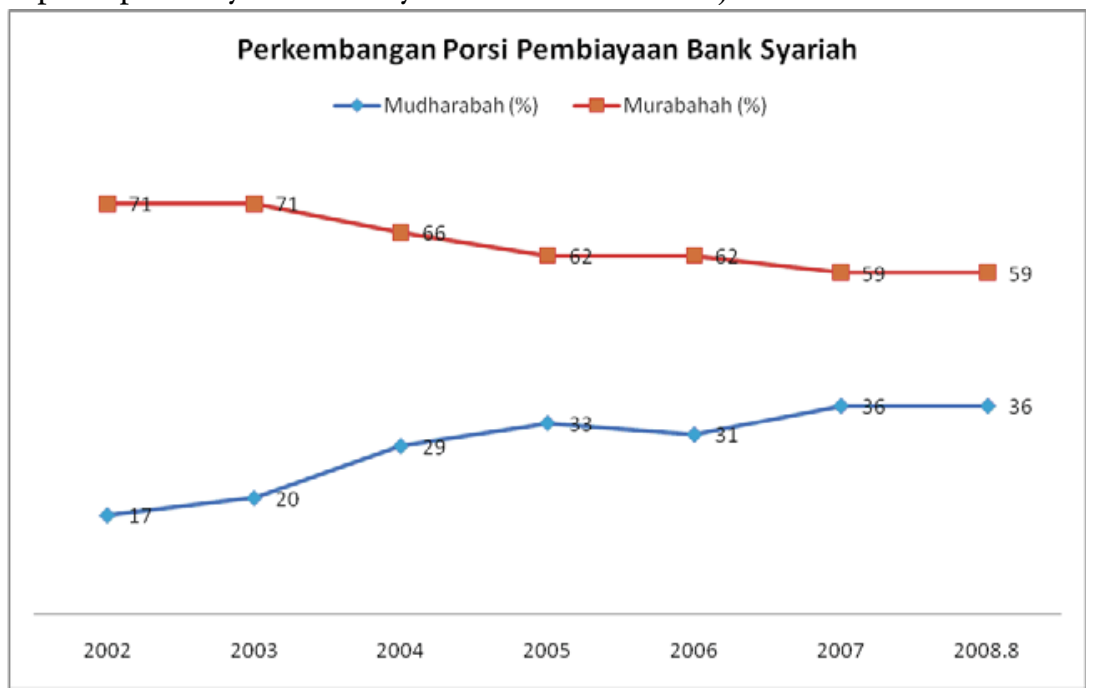

Gambar 4.2 Perkembangan Porsi Pembiayaan Bank Syariah 
Masalah rendahnya pembiayaan bagi hasil terbukti merupakan masalah yang multi dimensi yang mencakup berbagai pihak terkait, sehingga perlu adanya kesadaran bahwa masalah ini adalah masalah bersama yang memerlukan komitmen semua pihak terkait agar penyelesaian masalah dapat dilakukan secara komprehensif, sinergis, tuntas, dan berkesinambungan. Antisipasi terhadap masalah-masalah pokok yang ditemukan perlu segera dilakukan agar perkembangan pesat perbankan syariah tetap mengarah sesuai dengan arah dan tujuan pengembangan perbankan syariah yang diinginkan.

\section{SBI Syariah}

SBI Syariah telah diterbitkan pada akhir triwulan I 2008 atau pada Bulan April lalu. Ini merupakan salah satu instrumen likuiditas yang dimiliki perbankan syariah Indonesia. Sebagian pihak - khususnya kalangan praktisi industri perbankan akan berucap syukur atas lahirnya ketentuan baru ini. Namun sesungguhnya adanya SBI Syariah merupakan awal ketidakmampuan bank syariah dalam menyalurkan pembiayaan. Tidak ada alasan yang tepat dikeluarkannya SBI Syariah, sebab dengan adanya SBI Syariah akan mengurangi citra bank syariah yang selama ini konsen dalam pembiayaan ke sektor riil. Selama ini apa yang dilakukan oleh bank syariah sudah tepat di mana dalam menyalurkan pembiayaan (FDR) bank syariah sudah mencapai 100 persen lebih. Jika yang dipermasalahkan adalah resiko manajemen dalam pembiayaan ketika terjadi kredit macet (NPF) yang menjadi solusi bukan harus diterbitkannya SBI Syariah, akan tetapi sejauhmana bank syariah mau membenahi masalah marketing dan remidial. Meskipun memang ada ketentuan yang harus dimiliki oleh bank syariah yang menaruh dananya di SBI Syariah yaitu harus memiliki FDR sebesar $80 \%$. Jangan-jangan penyakit "playing safe" bank konvensional juga ikut menular kepada para eksekutor di industri perbankan syariah.

Penulis pahami secara gamblang bahwa salah satu perbedaan mendasar antara moneter syariah dan konvensional adalah terletak pada penggunaan instrumen moneternya yakni yang pertama dengan fasilitas bunga yang direpresentasi dengan SBI dan yang lainnya adalah bagi hasil. Dalam instrumen yang dipakai perbankan syariah dikenal dengan SWBI atau Sertifikat Wadiah Bank Indonesia. Ini semacam SBI-nya bank syariah. Dengan SWBI yang rendah, maka perbankan syariah cenderung enggan menyimpan dalam bentuk fasilitas tersebut. Sehingga dampak positifnya, dana yang ada akan lebih dipilih untuk dilemparkan ke sektor rill yang membutuhkan. Tidak seperti perilaku bank konvensional yang akan dengan nyaman menerima 'bonus' sekitar 8 hingga 9 persen per tahun dengan hanya berdiam diri sekalipun. Efek buruknya tentu saja dana tidak mengalir ke para debitur kecil. Namun setelah SBI Syariah lahir, maka hampir tidak ada bedanya antara perbankan "hijau" dan 'hitam'. Keduanya sama-sama tidak pro sektor riil. Bank syariah kemudian tidak punya 'genuine' 
dan cenderung hanya 'mirroring' belaka. Menurut penulis, hal ini adalah indikasi kurang baik dari sustainabilitas perbankan syariah Indonesia. Sehingga patut dipertanyakan, apakah hal ini adalah bentuk kekhawatiran bank konvensional ataukah malah kemanjaan bank syariah saja, yang seolah-olah sudah letih melempar dana ke masyarakat.

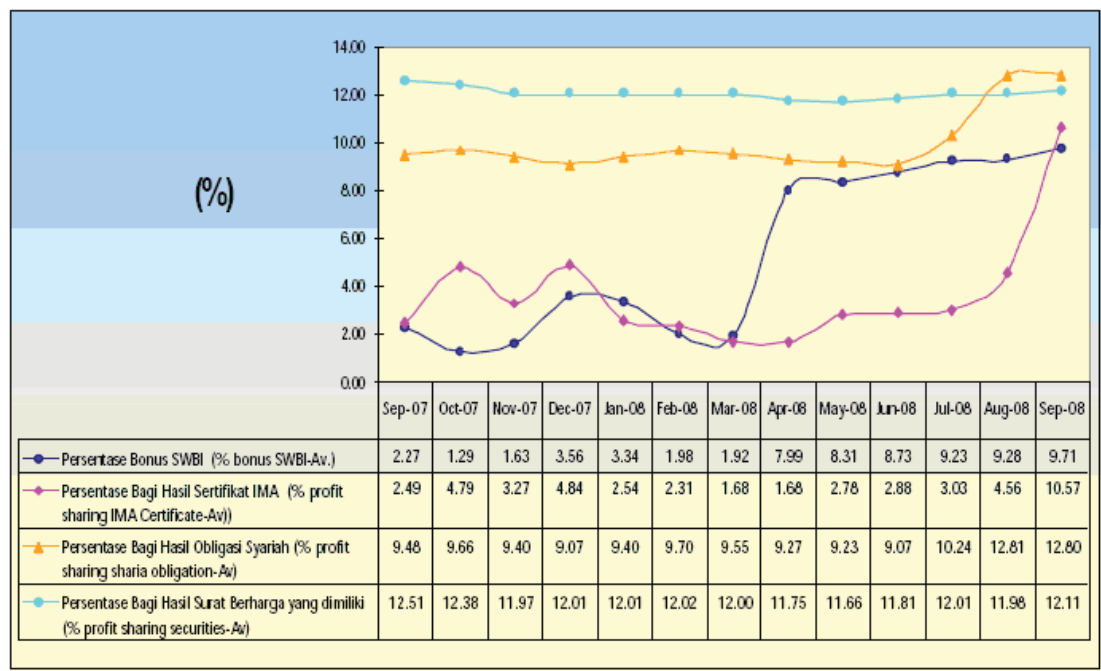

Sumber: Statistika Perbankan Syariab BI

Gambar 4.3 Bonus SBI Syariah

Ada beberapa implikasi negatif yang akan timbul. Pertama tentu saja FDR atau rasio dana yang diberikan kepada masyarakat yang tunamodal akan semakin turun dan susut, meski tidak akan secara langsung. Hal ini sangat dapat dipahami karena dengan iming-iming bonus (skim jualah) yang tinggi -sekitar 9 persen yang sama dengan nilai SBI- industri perbankan syariah seperti dihadapkan dengan hidangan yang super lezat tatkala sedang berpuasa. Tentu saja, yang keimanannya lemah akan dengan serta-merta melahap santapan di depannya tanpa perlu memikirkan ulang apakah hal itu baik baginya atau tidak. Dampak lain yang tidak kalah bahaya dan memiliki time lag yang cukup panjang adalah bank syariah bisa jadi akan kehilangan identitasnya. Nature atau genuinenya sudah sirna termakan pragmatisme. Atau mungkin juga ini adalah 'trap' yang dengan sengaja dipasang oleh pihak yang tidak senang dengan perkembangan alamiah bank syariah yang bombastis, dan sayangnya kita terperangkap dan terkena jeratnya. Semestinya yang lebih layak untuk dipikirkan untuk dijadikan solusi bukan SBI, akan tapi instrumen likuiditas lain seperti sukuk atau yang lainnya. 
Aam Slamet Rusydiana: Mencandera Industri Perbankan Syariah ...

\section{Kapitalisme Religius}

Secara garis besar ada tiga pilar sistem moneter yang membedakan satu dengan lainnya, yaitu sistem uang, sistem perbankan, dan sistem operasi keuangannya. Perbedaan utama sistem moneter Islam secara konseptual, sistem moneter Islam kontemporer dan sistem moneter konvensional ditunjukkan dalam tabel berikut. ${ }^{8}$

Tabel 4.1 Perbandingan Sistem Moneter Konvensional dan Islam

\begin{tabular}{|c|l|l|l|}
\hline No & \multicolumn{1}{|c|}{ Konvensional } & \multicolumn{1}{|c|}{ Islam Konseptual } & \multicolumn{1}{|c|}{ Islam Kontemporer } \\
\hline 1 & Sistem Uang Fiat & $\begin{array}{l}\text { Sistem Uang Islam - full bodied/ } \\
\text { backed money }\end{array}$ & Sistem Uang Fiat \\
\hline 2 & $\begin{array}{l}\text { Fractional Reserve } \\
\text { Banking System }\end{array}$ & $100 \%$ Reserve Banking System & $\begin{array}{l}\text { Fractional Reserve Banking } \\
\text { System }\end{array}$ \\
\hline 3 & Sistem Bunga & Profit Loss Sharing & Profit Loss Sharing \\
\hline
\end{tabular}

Sumber: Ascarya et al.(2007)

Dalam sistem keuangan ganda yang ada saat ini, hanya konsep bagi hasil saja yang menjadi pembeda antara sistem moneter konvensional dan sistem moneter Islam. Sistem moneter Islam dalam sistem keuangan ganda masih menggunakan uang fiat konvensional dan masih menerapkan fractional reserve banking system. Artinya, jika diibaratkan maka ke-Islaman bank syariah yang saat ini menjadi topik yang kita perbincangkan hanyalah sepertiga atau kira-kira sekitar 30 -an persen dari 100\% idealnya. Ditambah lagi dengan porsi bagi hasil yang juga terbilang rendah. Sehingga jika dikalkulasi akan menjadi hanya $20 \%$ saja bagian murni Islam dan $80 \%$ lainnya adalah masih belum ideal. Sehingga pantas apabila tidak sedikit pakar ekonomi Islam yang juga mengharamkan bank Islam. Diantaranya adalah sebagian mazhab pemikiran altrenatif-kritis.

Sudah banyak tulisan yang mengkritik terhadap ketidaksempurnaan aplikasi moneter Islam -termasuk juga bank syariah- yang kemudian dikenal dengan triple satanic finance system: bunga, uang kertas dan sistem cadangan bank sebagian. Iqbal dalam tulisannya misalnya menjelaskan bahwa jika uang yang kita gunakan adalah uang kertas yang bisa dicetak terus tanpa ada yang membatasinya, kemudian uang tersebut dengan sistem bunga 'ditarik' dari peredaran dan disimpan dalam bentuk tabungan, deposito dan lain sebagainya sehingga membuat sektor riil tidak bergerak, maka harga barang akan naik (baca: inflasi). Jika kenaikan ini berlangsung terus secara spiral akan dapat menimbulkan apa yang disebut sebagai hiperinflasi. Inflasi yang terjadi melalui proses demikian adalah inflasi yang dzalim karena didorong oleh kedzaliman pencetakan uang yang tidak terkontrol dan menahan uang dari sektor riil melalui mekanisme bunga bank yang ribawi. Selain kedzaliman dalam jumlah uang yang berlebihan,

${ }^{8}$ Ascarya (2007). Sistem Keuangan dan Moneter Islam, Pusat Pendidikan dan Studi Kebanksentralan, Bank Indonesia. 
kenaikan harga juga bisa terjadi karena penimbunan barang dan monopoli yang keduanya juga terlarang dalam Islam. ${ }^{9}$ Inflasi atau kenaikan harga-harga yang dzalim demikian -baik karena jumlah uang yang dicetak berlebihan atau ada tindakan yang tidak adil seperti penimbunan dan monopoli- menurutnya adalah kenaikan harga yang tidak dibolehkan dan bahkan harus dicegah.

Amin dalam bukunya juga memukul telak aplikasi fractional reserve banking. Ia mengatakan bahwa bank sentral sebuah negara mensyaratkan setiap bank yang beroperasi di wilayah otoritasnya untuk menyediakan atau menyimpan sebagian kecil dana yang disetorkan deposan sebagai cadangan. Inilah yang dikenal sebagai Fractional Reserve Requirment (FRR). Cadangan sebagian yang dipersyaratkan ini diperlukan untuk memenuhi kondisi normal permintaan dari para deposan yang menarik tabungan atau depositonya. Besarnya jumlah cadangan umumnya jauh di bawah $100 \%$. Itulah mengapa disebut sebagian kecil (fractional). Jika bank sentral mensyaratkan besarnya FRR 10\%, maka untuk besaran deposit Rp 100 juta, perlu menyediakan paling tidak cadangan sebesar Rp 10 juta. ${ }^{10}$

Dengan aturan main seperti ini, bank bisa leluasa meminjamkan $90 \%$ bagian lainnya kepada nasabah atau para deposan yang membutuhkan. Secara logis tidak ada yang bermasalah dari aturan ini. Namun dalam praktiknya, peraturan FRR menempatkan bank secara tidak langsung sebagai agen yang turut mempengaruhi suplai uang (money supply). Pendeknya, bank -bukan hanya Bank Sentral- telah ikut mencetak uang.

Amin mengilustrasikan bagaimana bank berperan dalam mencetak uang. Katakanlah Bank Sentral mensyaratkan rasio cadangan sebesar $10 \%$. Jika seseorang deposan menaruh uangnya di bank sebesar Rp 100.000, maka dari sisi bank, uang ini bisa digandakan sampai pada level maksimum Rp 1.000.000 (jumlah simpanan deposan dibagi dengan rasio persyaratan cadangan 10\%). Dalam kasus di atas, simpanan deposan itu akan dimasukkan dalam cash bank. Namun karena bank hanya perlu menyimpan $10 \%$ dari simpanan nasabahnya sebagai cadangan, maka bank bisa mencetak tambahan deposit baru. Hal ini dapat diciptakan melalui kredit yang diberikan bank, meskipun pada kenyataannya tidak ada nasabah baru yang menaruh uangnya di bank. Dan hal ini juga berlaku di perbankan syariah -termasuk transaksi uang kertas yang mengandung riba dan seigniorage. Maka, penulis ingin menyampaikan bahwa saat ini perbankan syariah memang pada kenyataannya masih jauh dari kesempurnaan. Ia ber-Islam namun hanyalah sebagian. Tentu saja hal ini bukan tidak mungkin menimbulkan dampak kurang baik. Bahkan dalam bukunya, The End of Economics, Umar Ibrahim Vadillo, pemimpin gerakan Murabitun Internasional memberikan kritik

${ }^{9}$ Muhaimin Iqbal (2007). Mengembalikan Kemakmuran Islam dengan Dinar dan Dirham. (Jakarta: Spiritual Learning Center-Dinar Club), hal... hal....

10 A. Riawan Amin (2007). Satanic Finance. (Jakarta: Celestial Publishing), 
Aam Slamet Rusydiana: Mencandera Industri Perbankan Syariah ...

yang cukup keras.

\section{E. Pro Rakyat Kecil}

Jika ada pertanyaan apakah bank syariah pro rakyat kecil, maka jawabannya adalah bahwa pada praktiknya saat ini bisa ya namun bisa juga tidak. Pandangan kritis yang menyebutkan bank syariah tidak pro rakyat kecil dapat ditelusuri dari deskripsi berikut. Keberpihakan bank lewat kredit adalah sebagai sebuah darah segar, tetapi meskipun demikian yang sering tersaji adalah ketimpangan kucuran kredit. Persentase kredit perbankan untuk perindustrian menghadirkan disparitas yang sangat tajam, yakni mencapai 23,28 persen, sementara untuk pertanian dan perikanan hanya 5,39 persen. Demikian juga dengan penyebaran kredit yang menunjukkan perbedaan yang cukup mencolok, di mana Rp 382,87 triliun disebar di Provinsi DKI yang merupakan 49 persen dari total kredit perbankan nasional. Padahal, pertumbuhan sektor pertaniannya hanya 0,69 persen (BPS 2000). Sisanya, sebanyak 51 persen disebar di 32 provinsi, di mana di daerah ini sektor pertanian lebih banyak mendominasi.

Begitu juga kalau ditinjau dari penerima kredit, tampaknya kredit perbankan begitu royal terhadap properti mewah, seperti apartemen. Untuk yang disebut terakhir ini, kredit yang dikucurkan mencapai Rp 33.069 miliar. Bandingkan dengan agrobisnis yang hanya menerima kucuran kredit sebesar Rp 11.329 miliar. Tentu saja hal ini tidak mengalunkan kecemasan seandainya sektor industri dihuni lebih sesak dari pada sektor pertanian. Tetapi, kenyataan sektor pertanian lebih riuh tenaga kerjanya. Pada 2006 ada 42,32 juta yang berteduh di sektor pertanian, meningkat lagi pada 2007, mencapai 42,61 juta jiwa.

Sementara itu, serapan tenaga kerja pada sektor industri pada 2007 hanya 12,09 juta jiwa, lebih tinggi dari tahun sebelumnya yang hanya 11,58 juta jiwa. Maka, dengan bahasa sederhana, ketika kucuran kredit lebih digelontorkan pada sektor pertanian, tentu dapat bermanfaat lebih banyak. Laju pertumbuhan pertanian tentu dapat didorong lebih kencang. Rasio yang diperankan perbankan sedikit sekali pada sektor pertanian. Pada awal musim tanam kekurangan modal sering menjadi pil pahit yang harus ditelan petani. Di sinilah seolah dosa perbankan, permohonan kredit yang berbelit dan berliku membuat petani harus bersimpuh di kaki para pengijon, tengkulak, bahkan rentenir.

Sektor pertanian, yang saat ini dapat menjadi penyumbang pertumbuhan PDB terbesar, bukan hanya mengalami penurunan pangsa pada pembiayaan syariah, tetapi juga mengalami penurunan outstanding dari tahun ke tahun dibandingkan tahun 2004. Sektor pertanian hanya berpangsa 2,54\% dari total pembiayaan yang diberikan perbankan syariah pada triwulan III-2007. Padahal pada 2004, sektor pertanian, sempat mendapatkan 7,59\% dari pangsa pembiayaan Syariah. Barulah pada akhir 2007, porsi pembiayaan syariah untuk pertanian kembali menunjukkan tren positif yang ditandai kenaikan, baik outstanding 
maupun sharenya.

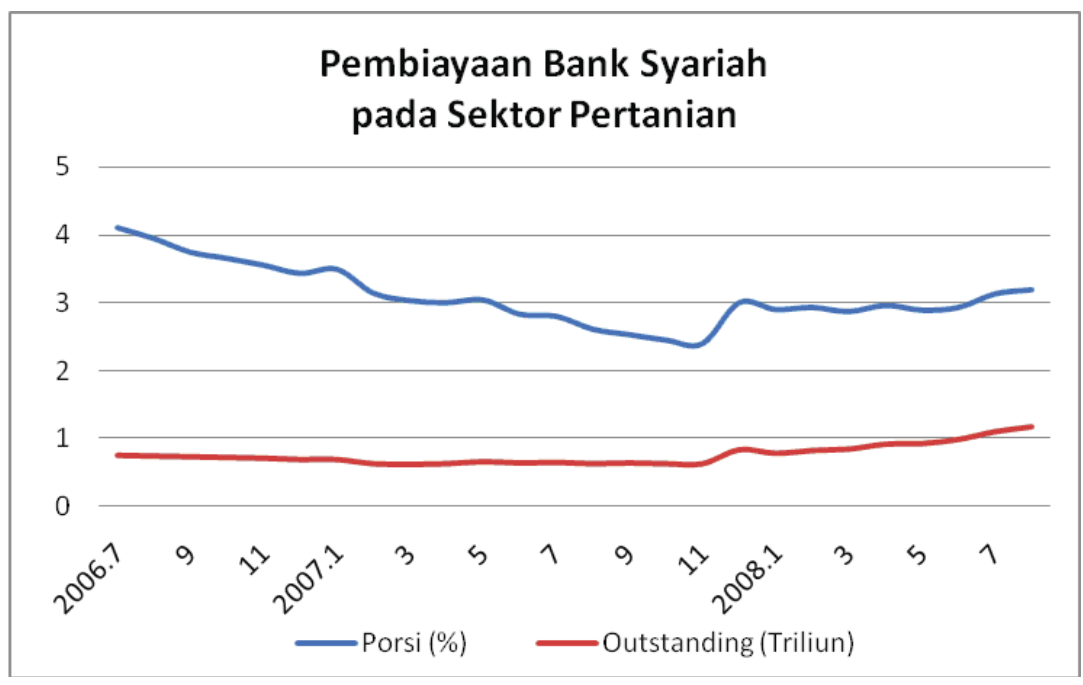

Gambar 4.4 Pembiayaan Syariah pada Pertanian

Dapat dilihat pada gambar di atas, setelah mengalami penurunan dari medio tahun 2006 yang sekitar 4,1\% hingga kuartal ketiga tahun 2007 (2,3\%), pembiayaan yang dilakukan industri perbankan syariah untuk sektor pertanian kembali naik menjadi 3,2\% pada Bulan Agustus 2008. Hal ini dicerminkan juga dengan kenaikan outstanding pembiayaan yang mencapai sekitar Rp 1,1 triliyun (Agustus 2008) dari awalnya hanya Rp 0,6 triliyun pada November 2007.

Sementara itu, di sisi perbankan konvensional masih lebih baik dari perbankan syariah dari hal penyaluran kredit ke sektor pertanian. Outstanding kredit yang diberikan perbankan komersial nasional dari tahun ke tahun mengalami kenaikan. Pada tahun 2002 yang hanya tercatat Rp 22,7 triliyun naik menjadi Rp 33,1 triliyun pada 2004, dan mencapai Rp 56,9 triliyun pada akhir 2007. Meskipun demikian, porsi persentase kredit sektor pertanian dari keseluruhan kredit yang dikucurkan perbankan nasional masih berada pada kisaran 5 hingga 6 persen setiap tahunnya.

Jika kita melihat data yang ada, pangsa pembiayaan syariah terbesar diberikan pada sektor jasa dunia usaha (30,25\% pada akhir tahun 2007), diikuti oleh sektor lain-lain/konsumsi (22,94\%) dan sektor perdagangan (15,62\%). Untuk data bulan Agustus 2008 umpamanya, pembiayaan bank syariah terbesar masih tetap didominasi sektor jasa dunia usaha (business services), yakni sekitar $31 \%$. Jauh lebih besar jika dibandingkan dengan pembiayaan sektor pertanian yang hanya lebih kurang 3\% saja. Dari komposisi tersebut, dapat dilihat bahwa lebih dari separuh pembiayaan syariah terdistribusi untuk penggunaan 
konsumsi. Hal ini menunjukkan komposisi pembiayaan yang berkaitan dengan konsumsi pada perbankan syariah jauh lebih besar dari komposisi yang ada pada perbankan umum nasional. Hal ini tentunya menjadi tantangan tersendiri bagi dunia perbankan syariah nasional kita. Selain itu, inti bagian ini juga ingin menjelaskan bahwa pada fakta empiris di lapangan, ternyata bank syariah masih sukar memberikan pembiayaan kepada para petani yang notabene adalah kaum lemah pedesaan yang mayoritas. Sektor pertanian yang adalah penyumbang PDB yang cukup besar, penyerap tenaga kerja yang baik dan menjadi sumber produksi dan ketahanan pangan Indonesia ternyata masih 'unbankable' bagi perbankan khususnya bank syariah.

\section{F. Social Multiplier Effect}

Masukan lain yang layak dilayangkan kepada entitas ekonomi Islam dan para penggiatnya, terutama industri perbankan syariah Indonesia adalah sudahkah industri keuangan syariah dari mulai bank, asuransi, pasar modal, dan industri keuangan lain mampu dan lihai dalam 'memberantas' kemiskinan dan pengangguran? Apakah perkembangan dan booming ekonomi syariah berkorelasi positif dengan pemusnahan ketimpangan sosial pada masyarakat? Data yang ada memaparkan dengan baik kepada kita bahwa ternyata angka kemiskinan dan pengangguran tetap saja tinggi bahkan naik. Semestinya rumus yang berlaku adalah setiap kenaikan share $0,1 \%$ perbankan syariah, misalnya, mampu mengurangi angka kemiskinan sebesar sekian juta atau sekian persen dari yang ada. Namun lagi-lagi, sayangnya hal itu hanyalah keinginan belaka. Angka kemiskinan masih tetap tinggi yakni sekitar 39 juta jiwa. Begitu juga pengangguran yang tidak kurang dari 12 juta jiwa. (Gambar 4.5)

Menarik, jika kita melakukan komparasi antara kasus di Indonesia dengan negara Muhamad Yunus, penerima nobel perdamaian dari Bangladesh. Mengapa perjuangan ekonomi syariah Indonesia yang dimulai sejak tahun 1992 belum menunjukkan hasil yang memuaskan, padahal hingga saat ini telah terhitung 15 tahun lamanya, sementara Grameen Bank dengan hanya waktu 10 tahun saja (1976-1980an) telah mampu mencapai prestasi yang tidak sederhana: membebaskan jerat kemiskinan penduduk Bangladesh? Padahal yang pertama telah dengan benar menggunakan konsep bagi hasil, sedang yang kedua masih bergelimang bunga? Yang pertama masih belum berhasil menurunkan struktur masyarakat miskin yang hingga saat ini terhitung sekitar 40 juta jiwa (18\%), sedang yang kedua telah sukses mengentas miskin dengan jumlah yang hampir sama? Nampaknya ada yang salah dengan perjuangan ekonomi syariah kita. 


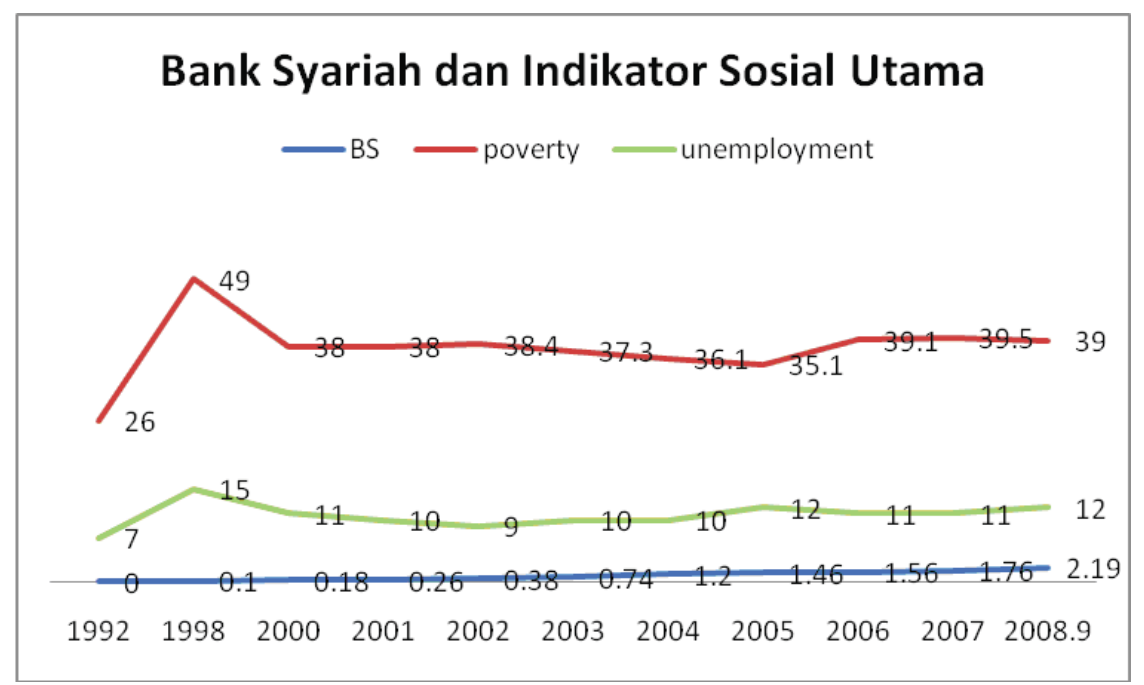

Gambar 4.5 Bank Syariah, Kemiskinan dan Pengangguran

Benang merah yang disampaikan dalam bagian ini adalah, selayaknya ekonomi Islam di Indonesia mampu menjawab dengan benar tantangan yang diberikan oleh perekonomian modern: ketimpangan sosial. Bank syariah kemudian dapat memberi efek multiplier sosial yang positif, dan bukan malah ikut menyumbang masalah. Jika saat ini ternyata hasilnya belum mencapai yang ideal, seyogianya kita mengevaluasi adakah jalan yang ditempuh dan instrumen yang digunakan salah? Perbankan syariah Indonesia harus secara cermat mengenal diri untuk kemudian melakukan koreksi andai ada hal yang tidak sesuai dengan yang digariskan syariat.

\section{Penutup}

Berdasarkan penjelasan panjang di atas, maka dapat ditarik beberapa kesimpulan penting, yakni:

1. Perkembangan industri perbankan syariah Indonesia ternyata sangat tergantung pada ada tidaknya dukungan dan political will dari pihak penguasa. Regulasi menjadi sesuatu yang niscaya. Undang-undang tahun 1992 dan 1998 menjadi bukti bahwa setelah kedua UU itu keluar, perkembangan yang pesat pada industri perbankan terjadi. Itu pula yang diharapkan dari terbitnya UU No. 21 tahun 2008 ini. Dengan dukungan dan kekuatan hukum yang jelas dan mendukung, diharapkan akan menjadi daya 'push' yang kuat bagi akselerasi perkembangan industri keuangan syariah.

2. Jika mencermati isi yang tersurat dalam UU, kita patut berdecak optimis. Pasal-pasal yang disepakati sudah 'on the track' dan benar. Meskipun ada 
sebagian kecil yang masih kurang ideal. Implikasi yang kemudian akan terjadi diprediksi positif akan mampu mengakselerasi secara cepat perkembangan perbankan syariah. Namun meskipun demikian, dampak jangka pendek masih tidak terlalu signifikan terasa. Pertumbuhan share masih berkisar $0,05 \%$ tiap bulan. Masih sangat kecil dari yang diharapkan. Target 5 persen pada akhir 2008 pun rasanya akan sangat sulit tercapai kecuali menunggu mukjizat di akhir tahun dengan misalnya pendirian bank umum syariah baru.

3. Dalam perkembangannya hingga kini, industri perbankan syariah di Indonesia masih terlalu bersifat pragmatis dibanding memilih untuk berdiri pada "ashoolah" (karakter asli) yang dimilikinya. Perbankan syariah Indonesia seiring berjalannya waktu, menjadi kian 'liberal' dari yang sebelumnya. Hampir mirip dengan yang terjadi di Malaysia. Misalnya dapat dilihat dari penggunaan instrumen dan produk yang 'dipaksakan', seperti: SBI Syariah untuk instrumen likuiditas, produk kartu kredit, atau produk lainnya. Jika diluar term perbankan, di sana ada pula pasar modal/uang syariah yang juga terlalu 'ikut pasar' dan kurang pas dengan nature Islam.

4. Di sisi lain yang juga cukup penting, ternyata eksistensi ekonomi dan keuangan syariah sampai saat ini, kurang begitu memiliki dampak signifikan terhadap penyelesaian masalah ketimpangan sosial termasuk pengurangan angka kemiskinan dan pengangguran. Share perbankan syariah yang kian bertambah tidak diiringi dengan pengurangan jumlah orang miskin dan menganggur di Indonesia. Hal ini tentunya menjadi pertanyaan besar bagi siapa saja yang mendeklarasikan diri menjadi pengusung ekonomi berbasis keadilan ini.

Selain itu, ada beberapa rekomendasi yang penulis berikan dalam rangka pengembangan bank syariah yang alamiah ke depan. Terutama pasca keluarnya UU 21 tahun 2008 ini, yakni:

1. Meski UU sudah ada pada posisinya yang benar, bukan berarti bank syariah sudah pada letaknya yang ideal pula. Beberapa fakta yang terjadi, masih ada hal-hal yang harus diperbaiki dan diamati ulang, umpamanya: masalah porsi pembiayaan yang terlalu kental dengan nonbagi hasil, penggunaan instrumen likuiditas SBI Syariah, kartu kredit syariah, dan lain sebagainya. Perlu kiranya kajian yang lebih mendalam yang bersifat empiris kuantitatif umpamanya, tentang dampak yang ditimbulkan instrumen-instrumen tersebut.

2. Purifikasi terhadap pelaksanaan praktek perbankan syariah merupakan agenda utama yang harus terus mendapat perhatian, karena dengan adanya proses purifikasi ini perbankan syariah diarahkan untuk terus memperbaiki praktekprakteknya untuk meningkatkan kemurniannya terhadap prinsip-prinsip syariah yang harus dipegang teguh (syaria compliance). Tidak kemudian malah hanya 'mirroring' dan tidak memunculkan karakteristik genuinenya. Hanya dengan alasan hendak mencapai target pangsa pasar tertentu kemudian 
meninggalkan orisinalitas yang dimilikinya.

3. Hendaknya perbankan syariah tidak menggunakan 'segala macam cara' dalam mencapai tujuan. Perbankan syariah juga harus sudah mulai memikirkan cara bagaimana menjadi solusi atas ketidakberdayaan masyarakat kecil. Sehingga benar-benar menjadi bank yang 'santun', tidak kehilangan sisi sosial dan juga berprofit tinggi. Green Banking.

\section{DAFTAR PUSTAKA}

A Riawan Amin (2007), Satanic Finance. Jakarta: Celestial Publishing. Aam Slamet Rusydiana (2008), "Determinan Inflasi Indonesia: Sebuah Perbandingan Pendekatan Islam dan Konvensional”, Skripsi pada Sekolah Tinggi Ekonomi Islam (STEI) Tazkia.

Ali Sakti (2007), Sistem Ekonomi Islam: Jawaban atas Kekacauan Ekonomi Modern. Jakarta: Paradigma \& Aqsa Publishing.

Ascarya, et al (2004), "Dominasi Pembiayaan Nonbagi Hasil di Perbankan

Syariah Indonesia", Pusat Pendidikan dan Studi Kebanksentralan, Bank Indonesia.

Ashari dan Saptana (2005), Prospek Pembiayaan Syariah untuk Sektor Pertanian”, Paper, Pusat Analisis Sosial Ekonomi dan Kebijakan Pertanian. Bogor.

Ascarya (2007), Sistem Keuangan dan Moneter Islam. Pusat Pendidikan dan Studi Kebanksentralan, Bank Indonesia.

Ihsan Arham (2008), Potensi Strategis Pertanian dalam Membangun Perekonomian Indonesia, Makalah.

Laporan Perekonomian Indonesia Tahun 2007. Bank Indonesia.

Mohamad Daud Ali(1998), Hukum Islam dalam Peraturan Hukum Negara Indonesia. Jakarta: Rajawali Press.

Muhaimin Iqbal (2007), Mengembalikan Kemakmuran Islam dengan Dinar dan Dirham. Jakarta: Spiritual Learning Center-Dinar Club.

Pusat Analisis Sosial Ekonomi dan Kebijakan Pertanian, Badan Penelitian dan Pengembangan Pertanian (2007), "Potensi Pembiayaan Syariah untuk Sektor Pertanian Padi dan Palawija di Jawa Barat", Paper.

Rahmat Ramadhani (2008), "Perbankan Syariah Menuju Era Tinggal Landas: Kajian dalam Perspektif Hukum Ekonomi Islam Indonesia”. Makalah. Yusuf Wibisono (2008), Menakar UU Perbankan Syariah. Makalah. 